This article was downloaded by: [University of Sussex Library]

On: 08 February 2015, At: 09:23

Publisher: Routledge

Informa Ltd Registered in England and Wales Registered Number: 1072954

Registered office: Mortimer House, 37-41 Mortimer Street, London W1T

3J H, UK

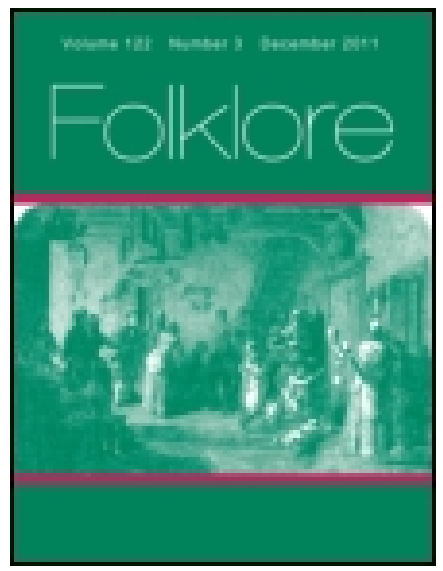

\title{
Folklore
}

Publication details, including instructions for authors and subscription information:

http:// www. tandfonline.com/loi/ rfol20

\section{Obituary. The Right Hon. F. Max Müller, K. M., LL.D., D.C.L.}

W. Crooke

Published online: 06 Feb 2012.

To cite this article: W. Crooke (1900) Obituary. The Right Hon. F. Max Müller, K. M., LL.D., D.C.L., Folklore, 11:4, 459-460, DOI: 10.1080/ 0015587X. 1900.9719603

To link to this article: http:// dx. doi. org/ 10.1080/0015587X.1900.9719603

\section{PLEASE SCROLL DOWN FOR ARTICLE}

Taylor \& Francis makes every effort to ensure the accuracy of all the information (the "Content") contained in the publications on our platform. However, Taylor \& Francis, our agents, and our licensors make no representations or warranties whatsoever as to the accuracy, completeness, or suitability for any purpose of the Content. Any opinions and views expressed in this publication are the opinions and views of the authors, and are not the views of or endorsed by Taylor \& Francis. The accuracy of the Content should not be relied upon and should be independently verified with primary sources of information. Taylor and Francis shall not be liable for any losses, actions, claims, proceedings, demands, costs, expenses, damages, and other liabilities whatsoever or howsoever caused arising directly or indirectly in connection with, in relation to or arising out of the use of the Content.

This article may be used for research, teaching, and private study purposes. Any substantial or systematic reproduction, redistribution, reselling, loan, sub-licensing, systematic supply, or distribution in any form to anyone is 
expressly forbidden. Terms $\&$ Conditions of access and use can be found at http://www.tandfonline.com/page/terms-and-conditions 


\section{OBITUARY.}

The Right Hon. F. MAX MÜLLER, K.M., LL.D., D.C.L.

Born 6th December, 1823 ; died 28th October, 1900.

By the death in the fulness of years of Professor Friedrich Max Müller, a notable figure disappears from the ranks of European men of science. A German by birth, he acquired to a remarkable degree the command of a lucid and even captivating English style; a scholar by profession, he was at the same time a man of the world, and the social influence which he thus secured was utilised in the popularisation of the studies to which his life was devoted. How great and how widespread an interest in Oriental studies, in language and mythology, he excited among his contemporaries, is shown by the number and variety of honours bestowed on him. He was a D.C.L. of five Universities-Cambridge, Dublin, Edinburgh, Bologna, and Buda-Pesth; one of the selected "foreign" members of three exclusive academies; and when the Chair of Comparative Philology was established at Oxford, he was designated in the foundation-deed as its first holder. And besides these academic distinctions, he received the star of the Medjidieh, the Swedish order of the Northern Star, the Legion of Honour, the orders of Albrecht the Bear and of the Crown of Italy; while in England, where he was accepted as perhaps no foreigner, save Handel, has ever been accepted, he alone among scholars was for his scholarship admitted to the Privy Council of the Sovereign.

Nor is it too much to claim as one result of his early contributions to the study of Comparative Philology and Comparative Religion, that the foundation of Societies such as our own is largely due to the interest in these subjects which they aroused. It is true that many of the conclusions at which he arrived have failed to stand the test of later criticism; but this, after all, is the fate of all pioneers of the New Learning. And he pointed out fields which others have since more effectually occupied. 
His main failing as a scholar was his unwillingness to reconsider his views when, once formulated, or to admit that anything was left for him to learn from a later generation. Even in Sanskrit his scholarship was unprogressive, and he could never be brought to see that he had overrated the influence of language in the development of mythology. .

He could never realise how much light is thrown on primitive religion by the investigation of popular beliefs, or that the study of the Vedas could be facilitated by an examination of the customs of the modern savage. That uncompromising opposition to the Anthropological school which appeared even in his last "Contributions to the Science of Mythology" seriously detracted from the value of his work. It was also unfortunate that he never visited India, and was never brought into contact with the modern creed on which the Vedas have left so little influence. If he had enjoyed the opportunity of exploring the shrines of Benares or Mathura, it is certain that he would have found it necessary to reconsider many of his views.

To a later age his reputation will probably in a great measure rest on his edition of the Rig Veda and on the great series of Oxford translations of the Sacred Books of the East and the records of Buddhism, which was due to his initiative. Though the execution was occasionally unequal, the collection as a whole is of the greatest value to all students of primitive religion. His later original work was of less importance, but he displayed a notable sympathy with the higher order of modern 'Hindu belief which some Anglo-Indians would be well advised to imitate:

W. Crooke. 